\title{
DEAD SHREWS ON THE ROAD: DISCARDED BY MAMMALIAN PREDATORS?
}

Spencer G. Sealy

Department of Biological Sciences

University of Manitoba

Winnipeg, MB R3T 2N2

Spencer.Sealy@umanitoba.ca

Many early naturalists suggested that weasels (Mustela spp.) discard shrews after they are captured..$^{1,2}$ This behaviour has been mentioned in many treatises on shrews and other mammals. ${ }^{3-6}$ Contrary observations abound ${ }^{5,7-9}$, however, and shrews have been recorded among the prey remains of some raptorial birds ${ }^{10}$, and also canid ${ }^{11,12}$ and other mustelid mammals. ${ }^{5,13}$ The idea that weasels in particular do not eat shrews has focused on glands that produce an odiferous substance that apparently renders shrews distasteful. The following observation in 1921 by Kirk (p. 111) $)^{14}$ of the Northern Shorttailed Shrew (Blarina brevicauda) in Vermont is enlightening:

In December the writer had a trap set for weasels under a brushy fence. The place was infested with blarinas and they were attracted to the rabbit bait and caught regularly. A weasel will take almost any kind of bait in the form of flesh, but tracks in the snow showed if a Bonaparte weasel approached the trap when it held a shrew, it kept at a distance of four inches and refused to touch the bait. The Blarina was removed and the next morning the trap held a weasel. The snow indicated that blarinas had run back and forth under the brush several times but the weasel was untouched.

Speculation regarding the unpalatability of shrews, originating from shrews found dead on roadways in New Brunswick, had been published in 1910: "Upon examination, ... always found them to have been killed by some preying mammal, probably the work of a weasel. The skulls have all been more or less broken, and at times, the skin about the fore parts punctured or badly mutilated. Cats will kill shrews, probably in mistake for mice, but they do not eat them as the shrews have a pungent musky odor obnoxious to carnivorous mammals."2

During ecological studies of passerine birds and interactions between hosts and the broodparasitic Brown-headed Cowbird (Molothrus ater) in a riparian forest at Delta Marsh ${ }^{15}$, Manitoba, I occasionally discovered dead shrews on the road that traversed the northern edge of the marsh. ${ }^{16}$ Examination of the carcasses revealed that each had been bitten by a mammal, most more than once, which suggested they had been discarded after being killed. I present evidence for this conclusion based on a sample collected between late May and early July 2000-2001.

\section{Study Area}

I opportunistically collected all but one of the shrews from $\sim 9 \mathrm{~km}$ of road that runs from Cram Creek to the hamlet of Delta, east of the Delta Marsh Field Station (University of Manitoba) and Assiniboine River Diversion (Figure 1), through the forested dune ridge that separates Delta Marsh from Lake Manitoba (5011' N, 98¹9' W), in the Aspen-Oak biotic zone. The south edge of the road was bordered by vegetation of Delta Marsh, whereas the northern edge abutted the upland vegetation of the dune-ridge forest (Figure 2). ${ }^{15,16}$ An exception was a $1.2-\mathrm{km}$ portion of the road that passed through the marsh. The shrews were collected between late May and early July, usually hundreds of metres apart. An additional specimen of North American Water Shrew (Sorex palustris) was collected from a road that transected a stand of White Cedar (Thuja occidentalis) at Birch Point $\left(49^{\circ} 10^{\prime} 4^{\prime \prime} \mathrm{N}\right.$, 95 $14^{\prime} 4$ " W), Lake of the Woods, Manitoba ${ }^{17,18}$, on July 1, 2001.16 Common and scientific names of mammals follow Naughton. ${ }^{6}$

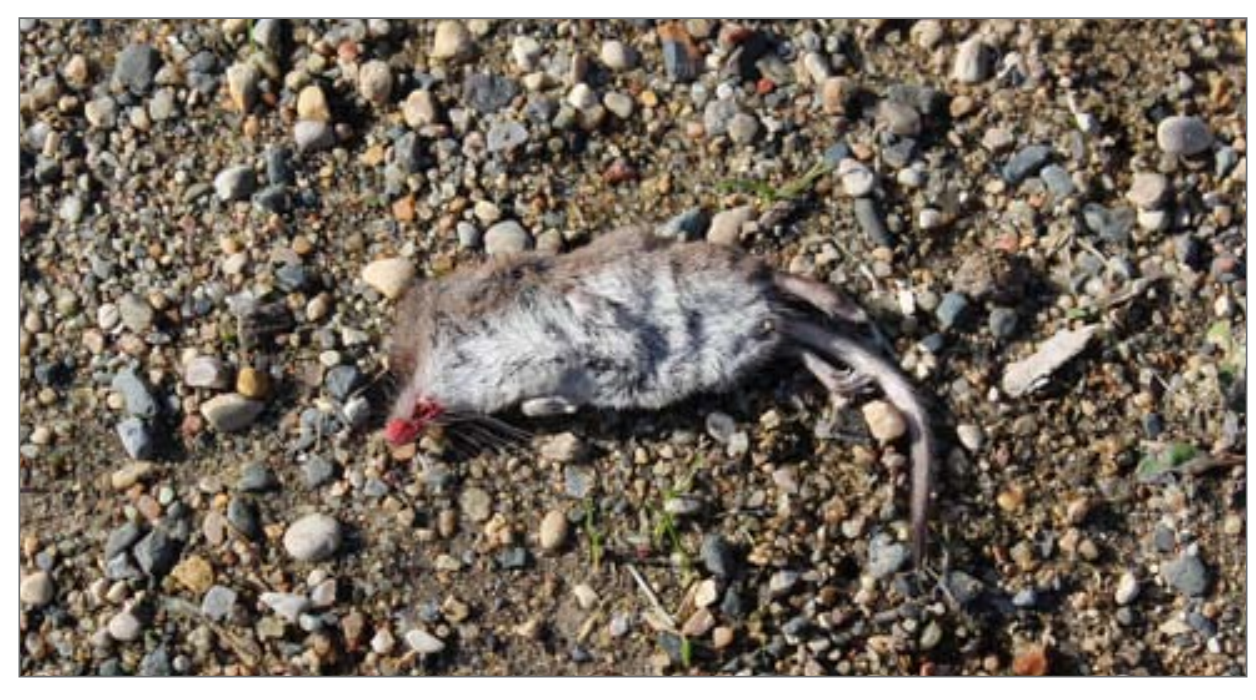

Dead shrew on the road. Photo credit: N.L. Sealy 


\section{Methods and results}

Shrews were generally fresh when discovered, usually with no external signs of trauma, although blood flowed from the nostrils or wounds in some. Fly eggs were recorded amid the hairs of one male Cinereus Shrew (S.cinereus) salvaged on June 26, 2001, which suggests I did not detect it the previous day. All shrews

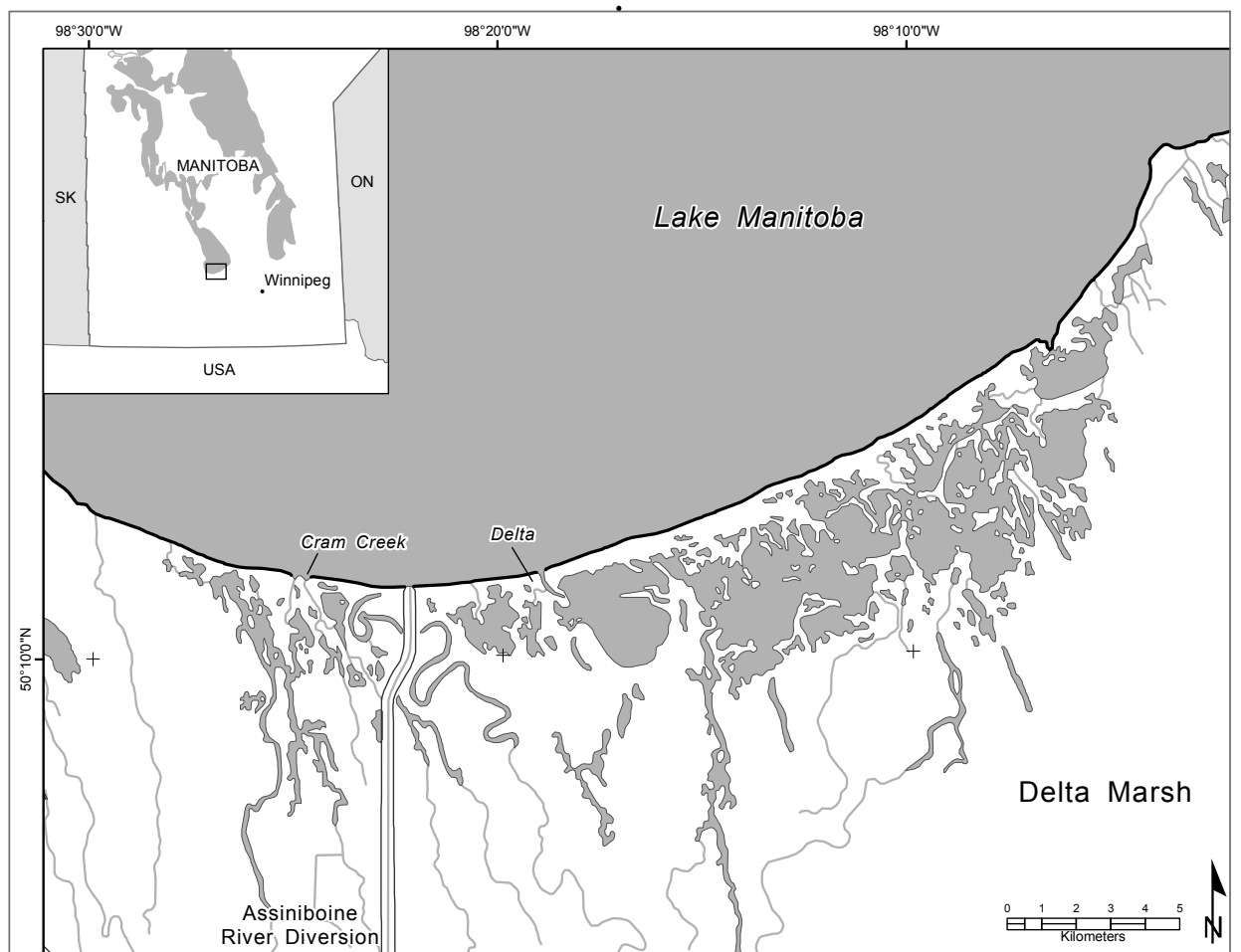

FIGURE 1. Location of study area (inset) and map of Delta Marsh, Manitoba, showing in bold the dune-ridge forest that separates Lake Manitoba and Delta Marsh, Manitoba. Map prepared by Mapmonsters GIS Ltd., Victoria, British Columbia.

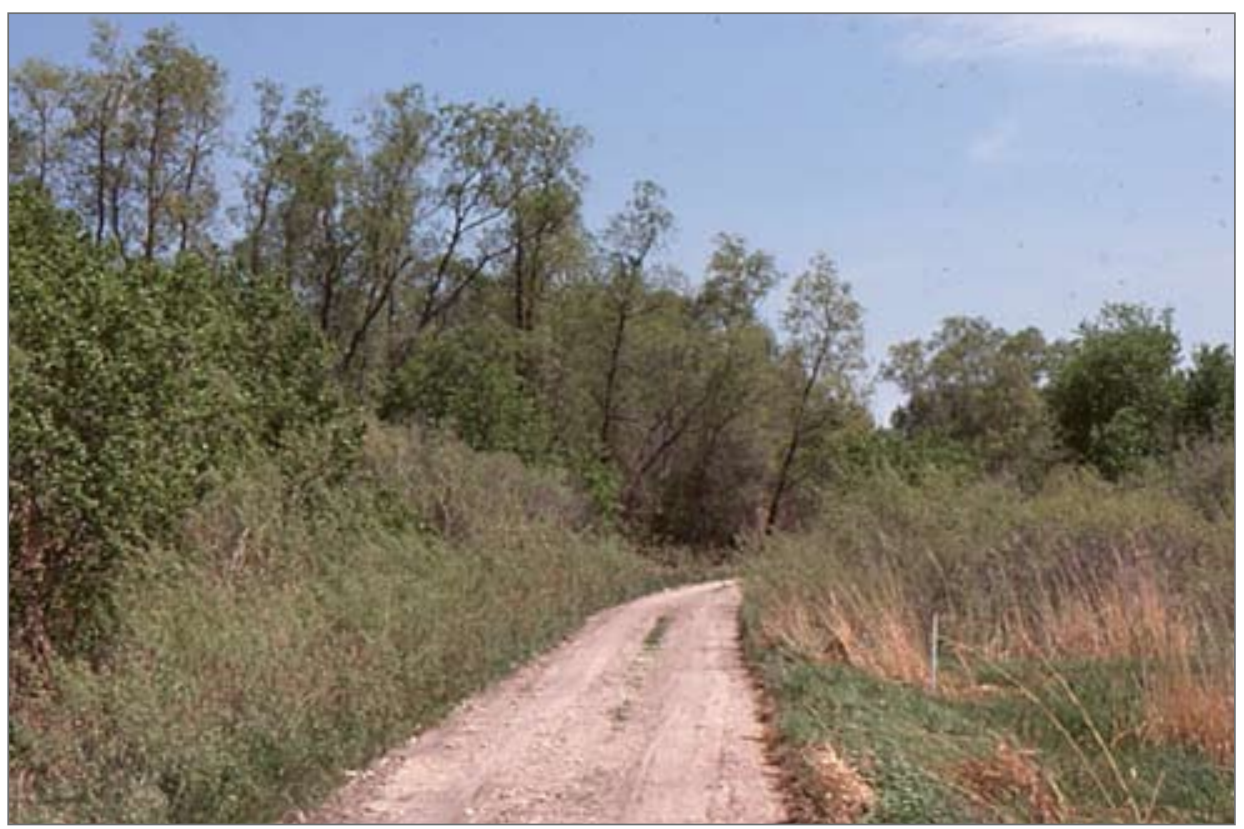

FIGURE 2. The road along the southern edge of the dune-ridge forest, Delta Marsh, on which dead shrews were found. To the north of the road (on the left) are Manitoba Maple (Acer negundo), Green Ash (Fraxinus pennsylvanica), Peach-leaved Willow (Salix amygdaloides), with Sandbar Willow (S. interior) along the edge, whereas along the south edge of the road are predominantly sedges (Carex spp.), Common Reed (Phragmites communis), and Sandbar Willow. had been bitten (Table 1), but no part of the body was eaten. One Cinereus Shrew was run over by a vehicle, possibly after it had been killed, but I did not include it in the sample. No dead shrews were discovered on the floor of the ridge forest or in vegetation of the marsh where I spent hundreds of hours searching for bird nests. I have no direct observations of capture and subsequent discarding of shrews by predators.

Each shrew was weighed to the nearest $0.1 \mathrm{~g}$, bagged, and frozen for later necropsy. I prepared some individuals as voucher specimens (Appendix 1). After thawing but before removing the skin, the maxillary teeth were exposed by pushing up the lips and gently opening the mouth. ${ }^{9}$ The identity of the morphologically similar Cinereus Shrew and possible specimens of North American Pygmy Shrew (S. hoyi) are based on microscopic examination of the number and relative size of the unicuspid teeth. Northern Short-tailed Shrew, Arctic Shrew and North American Water Shrew were initially identified on the basis of body size and characteristics of the pelage, but their identification was confirmed by examining teeth, in consultation with keys to the identification of shrews of the Canadian Prairie Provinces. ${ }^{5,19}$ Except for the voucher specimens, the skin and dissected bodies were refrozen, but most were subsequently destroyed when the contents of the freezer thawed following a fire in March 2009. ${ }^{16}$

A total of 68 individuals of four species of shrew was collected: Northern Short-tailed Shrew $(\mathrm{n}=$ 9), Arctic Shrew (S. arcticus, $n=$ 9), Cinereus Shrew $(n=47)$, and North American Water Shrew ( $\mathrm{n}=$ 3). Three to five voucher specimens of each species (Appendix I) were 
TABLE 1. Number of sets of bite marks (\%) recorded on 68 shrews found dead on roads at Delta Marsh and Birch Point, Manitoba, 2000-2001.

\begin{tabular}{|r|r|r|r|r|r|r|}
\hline SPECIES & ROSTRUM & OCCIPUT & \multicolumn{1}{r|}{ THORAX } & ABDOMEN & PELVIC REGION \\
\hline Blarina brevicauda $(\mathrm{n}=9)$ & 0 & $4(44.4)$ & $5(55.6)$ & $3(33.3)$ & 0 \\
\hline Sorex arcticus $(\mathrm{n}=9)$ & $1(11.1)$ & $4(44.4)$ & $5(55.6)$ & $1(11.1)$ & $1(11.1)$ \\
\hline Sorex cinereus $(\mathrm{n}=47)$ & $2(4.3)$ & $29(61.7)$ & $42(89.4)$ & $7(21.2)$ & 0 \\
\hline Sorex palustris $(\mathrm{n}=3)^{2}$ & 0 & $2(66.7)$ & $3(100)$ & 0 & 0 \\
\hline
\end{tabular}

1 Sample sizes for each category are greater than the number of individuals of each species examined, due to multiple bite marks inflicted on many individuals.

${ }^{2}$ One specimen was salvaged from a road at Birch Point, Lake of the Woods, Manitoba.

deposited in the mammal collection of The Manitoba Museum (MM). In addition, one adult male North American Pygmy Shrew was collected on June 20,2000 , but it was among the necropsied specimens lost in the fire before a voucher specimen could be prepared. This individual had been bitten on the skull/nape, thorax and abdomen; nevertheless, it was not included in the sample.

The entire skin was removed from each individual, except from the feet and tail. The position of each puncture wound on the body was recorded, identified by one or a pair of needle-like bite marks, i.e., single or pairs of canine teeth, which penetrated the skin and body on the dorsum and frequently the undersides of the shrews. The wounds were surrounded by bruises and subcutaneous hematomas on the inner, dermal surface (Figure 3) of all but nine shrews. Dermal bruising corresponded to the location of trauma of the underlying musculature. Of the 68 individuals collected, 109 sets of wounds were recorded from the following regions of the body, indicating most individuals were bitten more than once (Table 1): (1) rostrum (3/3 [100\%] crushed), (2) occiput of skull/nape of neck (hereafter, nape; 13/39 [33.3\%] crushed), (3) thoracic region (3/55 [5.5\%] torn), (4) abdominal region (0/11 [0\%] torn), and (5) pelvic region (0/1
[0\%] torn). Most shrews were bitten on both the occipital region of the skull/nape and thoracic region with similar frequency, rather than one bite either to one region or the other (Table 1). Thus, 94 sets of puncture marks $(86.2 \%)$ were recorded on the skull/nape and/or thorax, of which $16(17 \%)$ involved only the thorax. Eleven (11.7\%) shrews were punctured on neither the skull nor thorax. One front leg and one hind leg were bitten, in addition to the skull/nape, in one Northern Short-tailed Shrew and Arctic Shrew collected on June 20, 2000 and June 21, 2001, respectively. One adult male Northern Short-tailed Shrew (June 19, 2001) and one lactating Cinereus Shrew (June 13, 2001) were bitten once, both in the abdomen.

Shrews were sexed by dissection: Northern Short-tailed Shrew (5 adult Ђิઠ [55.6\%]: 4 우우), Arctic Shrew (7 adult $\widehat{\partial} \boldsymbol{O}^{\lambda}[77.8 \%]$ ]: 2 우우), Cinereus Shrew (25 adult ठోठ [73.5\%]: 9 우우; 6 juvenile $\widehat{\partial} \widehat{\partial}[46.2 \%]$ : 7 우우), and North American Water Shrew (0 ठ̋ [0\%]: 1 우우; 2 juvenile 우우). Four individuals (all Cinereus Shrews) were not aged, but of the remaining 64 individuals, 37 (57.8\%) were adult males, 16 (25\%) adult females, and 11 juveniles (17.2\%).

The width of the space between puncture wounds on the shrews' skin, likely made by upper canines (Figure 3), was measured (one wound per individual) with calipers

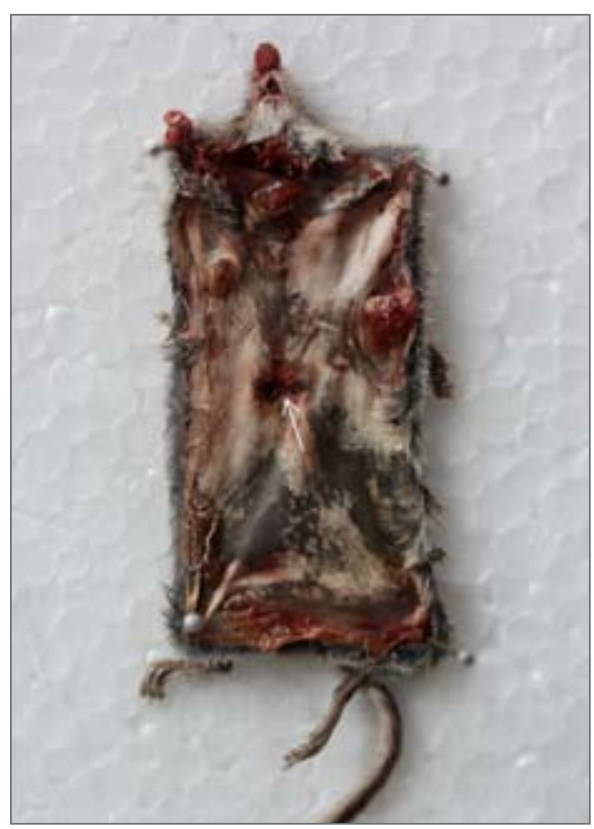

FIGURE 3. Bite marks on the underside of the skin in the thoracic region of a Cinereus Shrew (Sorex cinereus). The arrow points to the mid-point between the punctures apparently inflicted by upper canines of a weasel, $5.4 \mathrm{~mm}$ apart. The shrew also was bitten on the rostrum.

to the nearest $0.1 \mathrm{~mm}$ : Northern Short-tailed Shrew (5.8-6.5 mm; $\mathrm{n}=$ 2), Cinereus Shrew (5.4-6.2 mm; $n=$ 3), Arctic Shrew (6.1 mm, $\mathrm{m}=1)$, and North American Water Shrew (6.3 $m m ; n=1)$. Assuming the predator was a weasel, the widths between the upper canines of four species of mustelid were measured to the nearest $0.1 \mathrm{~mm}$ : Ermine (Mustela ermine, 5.1-6.9 mm, $\mathrm{n}=9$ ), Longtailed Weasel (M. frenata, 8.1-9.1 $\mathrm{mm}, \mathrm{n}=5)$, Least Weasel (M. nivalis, 3.2-4.4 mm, $\mathrm{n}=8$ ), and American Mink (Neovison vision, 8.4-8.9 mm, $\mathrm{n}=5$ ) for individuals in the mammal collection of The Manitoba Museum.

In addition to the shrews, five freshly dead Meadow Jumping Mice (Zapus hudsonicus) were collected from the same road between May 25 and June 27, 2000. The four adult males and one lactating female were examined as described above for the shrews and were preserved as voucher specimens (Appendix I). The 
cause of death was not determined for any of these individuals but, in contrast to the shrews, there were no puncture marks or hematomas on the under surface of the skin. No jumping mice were found dead in a previous or subsequent year, although individuals were flushed occasionally from tall grass.

Each species of shrew and the Meadow Jumping Mouse have been recorded previously at Delta Marsh. ${ }^{18,20-24}$ Northern Short-tailed Shrew, Arctic Shrew and Cinereus Shrew were described as the most abundant shrews at Delta Marsh, whereas North American Water Shrew and North American Pygmy Shrew were much less common. No studies of the population dynamics of these species have been conducted at Delta Marsh. All of the shrews except North American Water Shrew were recorded as prey of the Longtailed Weasel at Delta Marsh. ${ }^{13}$ An unidentified weasel with a Meadow Jumping Mouse in its mouth was observed at Delta Marsh ${ }^{25}$ and this species was among prey taken by a nesting pair of Northern Saw-whet Owls (Aegolius acadicus) in 200024, the year the dead jumping mice were collected from the road (Appendix 1).

\section{Discussion}

The evidence I present is consistent with the idea that the shrews discarded on a road were killed by a mammalian predator, probably a weasel. The data derived from dissections revealed that each shrew had been bitten and apparently killed and discarded by a mammal, possibly the Ermine, which was the most frequently observed species of weasel. In support of this was the width between bite marks on the skin most closely matched the width between the upper canines of the Ermine. Although the Long-tailed Weasel was abundant and frequently observed at Delta Marsh in the early years of the study ${ }^{13}$, I did not observe it after the mid-1990s. Least Weasels are present but uncommon at Delta Marsh $^{22}$ and the width between bite marks on the skin was less than what would have been inflicted by the larger American Mink.

Questions remain. I would not have recorded shrews that may have been eaten; therefore, were the dead shrews examples of surplus killing ${ }^{26}$, perhaps when other prey was not in short supply? Would male and female shrews, whose scent glands are most developed during the breeding season 27,28 , be discarded with the same frequency during the nonbreeding season? Had the shrews died of other causes on or off the road, before being bitten and discarded? If at least some shrews had died of other causes, presumably I would have discovered individuals, unbitten, as in the case of the Meadow Jumping Mice. Despite spending most of my time in habitats off the road, I never found dead shrews, although they would have been easily overlooked amid the dense vegetation.

The preponderance of bites to the neck or thorax of the shrews (Table 1) is consistent with the most commonly reported prey-killing technique of mustelids, particularly the mustelines $29-30$; that is, "biting the back of the neck or base of the skull, thus severing the spinal cord or crushing the occipital region. "29 Multiple bites on most individuals are also consistent with observations of weasels subduing prey in captivity. ${ }^{31-}$ 33

My observations are tantalizing, but the answer to the question of why weasels sometimes kill and discard shrews, whether because of their distasteful flavour or bad odor, or for some other reason, requires controlled experiments - standard behavioural choice tests that would involve captive weasels and shrews, or their scent, as the smallest shrews, with their rapid metabolism, soon die in captivity. ${ }^{3,6}$ Further research is also required to determine the function of the secretion of the flank glands of shrews and the odour produced. The glands and, hence, odour are most developed during the breeding season, which suggests the odour plays a reproductive role, possibly to aid shrews in finding receptive mates. $^{4}$

\section{Acknowledgements}

I am indebted to the personnel of the former Delta Marsh Field Station (University of Manitoba) for accommodation and in-kind support, and to many students and other co-workers for support with field work. The board of the Portage Country Club granted permission to conduct some of the field work on their property. C. Piper and A. Andries helped compile the data. Randall Mooi permitted me to measure weasel teeth in the mammal collection of The Manitoba Museum. Craig Willis, University of Winnipeg, offered thought-provoking comments on the manuscript. The map was prepared by Mapmonsters GIS Ltd, Victoria, British Columbia, with assistance from Nikola Zukanovic. Research at Delta Marsh was funded chiefly by the Natural Sciences and Engineering Research Council of Canada.

\section{Literature Cited}

1. Adams LE (1910) A hypothesis as to the cause of the autumnal epidemic of the Common and the Lesser shrew, with some notes on their habits. Proceedings of the Manchester Literary and Philosophical Society 54:1-13.

2. Moore WH (1910) A shrew new to New Brunswick. Ottawa Naturalist 23:217-218.

3. van Zyll de Jong CG (1983) Handbook of Canadian Mammals. Volume 1. Marsupials 
and insectivores. National Museums of Canada, Ottawa, ON.

4. Churchfield S (1990) The Natural History of Shrews. Comstock, Ithaca, NY.

5. Pattie DL, Hoffman RS (1999) Mammals of the North American Parks and Prairies (Third edition). Edmonton, $A B$.

6. Naughton D (2012) The Natural History of Canadian Mammals. Canadian Museum of Nature and University of Toronto Press, Toronto, ON.

7. Hamilton Jr, WJ (1928) Weasels eat shrews. Journal of Mammalogy 9:249-250.

8. King C (1990) The Natural History of Weasels and Stoats. Comstock, Ithaca, NY.

9. Nagorsen DW (1996) Opossums, Shrews and Moles of British Columbia. Royal British Columbia Museum Handbook, Volume 2.

10. George SB, Choate JR, and Genoways $\mathrm{HH}$ (1986) Blarina brevicauda. Mammalian Species, Number 261.

11. Fowle CD, Edwards RY (1955) An unusual abundance of Short-tailed Shrews, Blarina brevicauda. Journal of Mammalogy 36:36-41.

12. Etnier DA (1989) Small mammals of the Boundary Waters Canoe Area, with a second Minnesota record of the Heather Vole, Phenacomys intermedius. Canadian Field-Naturalist 103:353-257.

13. Gamble RL (1981) Distribution in Manitoba of Mustela frenata longicauda Bonaparte, the Long-tailed Weasel, and the interrelation of distribution and habitat selection in Manitoba, Saskatchewan, and Alberta. Canadian Journal of Zoology 59:1036-1039.

14. Kirk GL (1921) Shrews and weasels. Journal of Mammalogy 2:111.

15. MacKenzie DI (1982) The dune-ridge forest, Delta Marsh, Manitoba: Overstory vegetation and soil patterns. Canadian FieldNaturalist 96:61-68.

16. Sealy SG (2013) Specimens of North American Water Shrew from Delta Marsh, Manitoba. Blue Jay 71:94-97.

17. Buckner CH, Ray DGH (1968) Notes on the water shrew in bog habitats of southeastern Manitoba. Blue Jay 26:95-96.

18. Wrigley RE, DuBois JE, Copland HWR (1979) Habitat, abundance, and distribution of six species of shrews in Manitoba. Journal of Mammalogy 60:505-520.
19. Beck WH (1958) A guide to Saskatchewan Mammals. Saskatchewan Natural History Society, Special Publication Number 1.

20. Soper JD (1946) Mammals of the northern Great Plains along the international boundary in Canada. Journal of Mammalogy 27:127-153.

21. Krutzsch PH (1954) North American jumping mice (genus Zapus). Publications of the Museum of Natural History, University of Kansas 7:349-472.

22. Tamsitt JR (1962) Mammals of the Delta Marsh region of Lake Manitoba, Canada. Canadian Field-Naturalist 76:71-78.

23. Hochbaum PW (1971) The Delta Marsh. Manitoba Department of Mines, Resources and Environmental Management, Conservation Extension Branch, Winnipeg, Manitoba.

24. Underwood TJ, Sealy SG (2002) Breeding status and notes on diet of the Northern Saw-whet Owl at Delta Marsh, Manitoba. Blue Jay 60:130-135.

25. Quimby DC (1951) The life history and ecology of the Jumping Mouse, Zapus hudsonius. Ecological Monographs 21:61-95.

26. Kruuk H (1972) Surplus killing by carnivores. Journal of Zoology, London 166:233-244.

27. Pearson OP (1946) Scent glands of the Short-tailed Shrew. Anatomical Record 94:615-629.

28. Eadie WR (1938) The dermal glands of shrews. Journal of Mammalogy 19:171-174.

29. Ben-David M, Pellis SM, Pellis VC (1991) Feeding habits and predatory behaviour in the Marbled Polecat (Vormela peregusna syriaca): I. Killing methods in relation to prey size and prey behaviour. Behaviour 118 $(1-2): 127-142$

30. Wobeser G (2000) Suspected surplus killing of grebes by mink. Blue Jay 58:137-139.

31. Allen DL (1938) Notes on the killing technique of the New York weasel. Journal of Mammalogy 19:225-229.

32. Llewellyn LM (1942) Notes on the Alleghenian Least Weasel in Virginia. Journal of Mammalogy 23:439-441.

33. Heidt GA (1972) Anatomical and behavioral aspects of killing and feeding by the Least Weasel, Mustela nivalis L. Proceedings of the Arkansas Academy of Sciences 26:53-54.

\section{Appendix 1}

Voucher specimens of Northern Short-tailed Shrew (Blarina brevicauda), Arctic Shrew (Sorex arcticus), Cinereus Shrew

(S. cinereus), North American Water Shrew (S. palustris), and Meadow Jumping Mouse (Zapus hudsonicus) found dead on roads at Delta Marsh and Birch Point, Lake of the Woods, Manitoba. The specimens, with measurements, were deposited in The Manitoba Museum (MM).

Blarina brevicauda: (1) adult male (MM 24137), 30.3 g, 22 May 2000; (2) lactating female (MM 24138), $32.1 \mathrm{~g}, 20$ June 2000; (3) pregnant female, 10 fetuses (MM 24139), 35.6 g, 19 June 2001; and (4) adult male (MM 24140), 25.6 g, 19 June 2001.

Sorex arcticus: (1) adult male (MM 24141), 10.7 g, 19 June 2000; (2) juvenile female (MM 24142), 7.6 g, 24 June 2000; (3) adult male (MM 24143), 11.0 g, 27 June 2000;

(4) adult male (MM 24144), 11.4 g, 21 May 2001; and (5) adult male (MM 24145), 10.8 g, 13 June 2001.

Sorex cinereus: (1) male (MM 24147), 5.3 g, 24 June 2000; (2) male (MM 24150), 4.9 g, 12 June 2001 ; (3) lactating female (MM 24148), $6.1 \mathrm{~g}, 13$ June 2001; (4) male (MM 24149), 4.7 g, 21 June 2001; and (5) male (MM 24151), 5.2 g, 21 June 2001.

Sorex palustris: (1) lactating female (MM 24040), 19.1 g, 6 June $2001^{16}$; (2) juvenile female (MM 24041), 8.4 g, 12 June 2001 (see Sealy 2013); and (3) juvenile female (MM 24146), 11.4 g, 1 July 2001 (Birch Point, Manitoba).

A single specimen of a male Sorex hoyi was lost following a melt-down of a freezer during a fire in March 2009. ${ }^{16}$

Zapus hudsonicus: (1) adult male (MM 24155), 17.9 g, 25 May 2000; (2) adult male (MM 24153), 15.3 g, 4 June 2000; (3) adult male (MM 24154), $21.1 \mathrm{~g}, 16$ June 2000;

(4) (MM 24156), 18.4 g, 16 June 2000; and (5) lactating female (MM 24152), $23.3 \mathrm{~g}, 27$ June 2000. 